\title{
USING THE 3I+E FRAMEWORK TO ASSESS PROVINCIAL POLICY DECISIONS FOR THE SALE OF CANNABIS IN ONTARIO, SASKATCHEWAN AND QUEBEC
}

\author{
Ravinder Sandhu ${ }^{1}$, Guneet Saini ${ }^{1}$ and Elizabeth Alvarez ${ }^{1}$ \\ ${ }^{1}$ Department of Health Research Methods, Evidence and Impact, McMaster University, Hamilton, Canada \\ Corresponding author: Ravinder Sandhu, ravsandhu5@gmail.com
}

\begin{abstract}
Objective: This paper examines policy decisions regarding public or private retail models chosen for the recreational use of cannabis in the provinces of Ontario, Saskatchewan and Quebec to demonstrate the application of the 3I+E framework for policy analysis.
\end{abstract}

Methods: The 3I+E framework includes considerations of institutions, interests, ideas and external factors that play a role in adopting a particular policy. A retrospective comparative approach using this framework was conducted. Relevant newspaper articles, press releases, consultation reports and primary policy papers were reviewed.

Results: The province of Ontario has a mixed model for the sale of recreational cannabis, while Saskatchewan's recreational cannabis is fully private and retail in Quebec is through the public sector. Government institutions, particularly the party in power and the number of seats they hold, as well as existing policy legacies for alcohol retail, appeared to strongly influence the policy decisions in all three jurisdictions. Interest groups, including municipal and labor unions and private cannabis companies had a limited role in swaying government decisions toward a particular model. Beliefs and values of citizens regarding cannabis retail did not appear to play a significant role. In Ontario particularly, an external factor, namely a major political shift towards a conservative government had a large role in the mixed model chosen in the jurisdiction.

Conclusion: Overall, the policy decision for cannabis retail is multifactorial and the interaction between stakeholders and interest groups with the government influences which model was ultimately chosen in each jurisdiction.

Keywords: Cannabis, Policy making, Government, 3I+E framework, Comparative analysis, Cannabis retail

\section{Introduction}

On October 17, 2018, Canada implemented the Cannabis Act, Bill C-45, becoming one of the first countries in the world to legalize recreational cannabis on a national scale. ${ }^{1}$ A relevant outcome of this decision was the policy implications for recreational cannabis retail models that would be chosen to sell cannabis within each province. As a decentralized, federal state, Canada's legislative powers are distributed between provincial and federal levels of government, as enumerated in the Constitution Acts, 1867 and 1982. ${ }^{2}$ Provinces were responsible for adopting their own retail models for cannabis, leading to a wide variety of practices chosen for in-store and online sales. Retail models for cannabis sale include private models, as was chosen in Saskatchewan, in which private companies must obtain licenses authorized by the provincial government to open cannabis retail stores. Quebec selected a public model, in which a crown corporation or provincial board controls the retail. A hybrid or mixed-model was selected in Ontario, where a component of retail, either online or in-store distribution is privatized, while the other is controlled by the provincial government. ${ }^{3}$ 
The rationale for each province's chosen model was not made clear by policymakers or government officials. However, the choice to sell through the private or public sector has economic and public health implications. The model chosen can influence the availability and method of delivery of cannabis, which has important implications for cannabis including use by youth, crime rates, emergency department visits associated with cannabis use, road safety and more. ${ }^{3}$ Experts advocating for public monopolies believe that private models could increase overuse by at-risk populations because they would be less stringent in demanding identification and complying with federal regulatory limits compared to government-controlled storefronts. ${ }^{3}$ On the other hand, there is support for privatization as a means to keep product prices low through competition, and to better compete with the illegal market. ${ }^{3}$

The 3I+E framework can be applied to explore how the policy decisions pertaining to the retail of recreational cannabis were formulated and the potential implications of its implementation. The $3 \mathrm{I}+\mathrm{E}$ framework provides a conceptual blueprint that can be used to analyze the factors that shape policy making. ${ }^{4}$ The framework consists of institutions, interests, ideas (hereinafter referred to as the 3Is) and external factors - all of which interact and influence the policy making process (see Figure 1). It provides a helpful tool for analyzing policy decisions as it outlines the key elements that influence whether or not a decision moves forward towards implementation. This allows policy analysts to further evaluate what seemed to matter most in pushing the policy in question forward or what played an insignificant role.

The 3Is have been helpful in analyzing policy decisions in topics of healthcare policy as well. For instance, it has been used to analyze policies related to child heath in West Africa and to compare prescription drug policy-making processes in Canadian provinces. ${ }^{5}$

There is a gap in publicly available information regarding the reasons why provinces in Canada selected their respective retail models for cannabis, which is relevant when exploring the risks and benefits of each approach in the short and longterm. The objective of this paper is to apply the $3 \mathrm{I}+\mathrm{E}$ framework to explore how the policy decisions for the retail of recreational cannabis were made by the provinces of Ontario, Saskatchewan and Quebec.

\section{Methods}

\section{Selection of Jurisdictions}

Ontario, Saskatchewan and Quebec were selected to explore differences in how the decision to choose a private, public or mixed retail model can be made due to their varying geographical locations across Canada, their diverse political histories and the varying models chosen by each jurisdiction.

\section{Description of $3 I+E$ framework}

\section{Institutions}

The first "I" in the framework, institutions, can be further divided into government structures, policy legacies and the policy networks that are in place within a jurisdiction. ${ }^{5,6}$ Government structures refer to the system of political arrangements within a jurisdiction, such as the levels and branches of government and political party structures. ${ }^{7}$ Canada has a federal parliamentary system which governs via the executive, legislative and judiciary branches. ${ }^{8}$ For a bill to pass and be maintained, the approval and agreement of these different branches are needed. A veto player can be an individual or a collective actor, agreeing to or blocking a policy. ${ }^{9}$ In the Canadian parliamentary system, once a government becomes the majority party, strong party discipline between members, which is when members of a party vote the same way on an issue or policy, plays a significant role in allowing a policy to move forward or be blocked. ${ }^{9,10}$ 


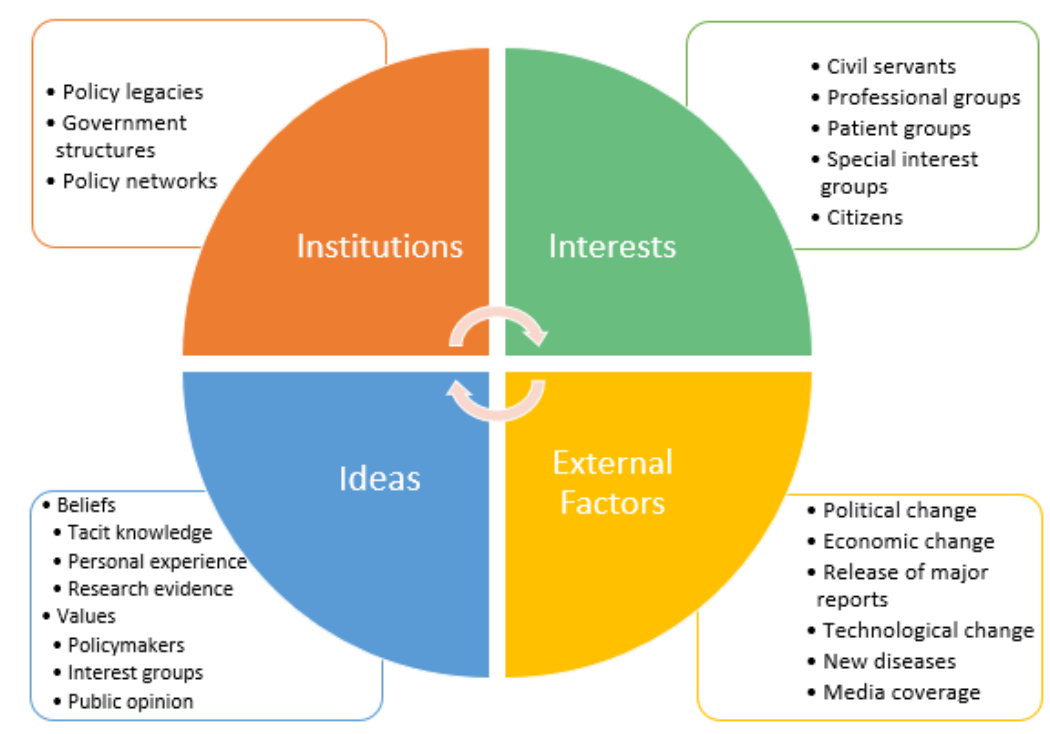

Figure 1. An illustration of the four factors within the $3 \mathrm{I}+\mathrm{E}$ framework and the elements to consider under each factor. Adapted from Lavis et al. 2012

https://doi.org/10.1371//ournal.pmed.1001186.

Another element within institutions are policy legacies, which describe the influence of past policies within a jurisdiction and their subsequent "path dependence", in which it becomes difficult to deviate from the path created by previous choices and achieve policy reform. ${ }^{11}$

Finally, policy networks characterize the interplay between government institutions and interest groups. ${ }^{12}$ These networks define the types of arrangements which allow certain groups to engage with the policy making process and influence political actors. ${ }^{13}$ For example, in a pressure pluralist policy network, the government acts as an autonomous player, and external actors, both businesses and non-businesses, attempt to influence policy, whereas in a corporatist network, few powerful groups participate in policy decision making along with the government, rather than many groups advocating for policy decisions. ${ }^{13,14}$

\section{Interests}

The second "I" within the framework, interests, refers to stakeholders within society that attempt to sway policy decisions to their advantage but do not seek political power. ${ }^{15}$ This often leads to collective action through the formation of various types of interest groups, such as professional groups, patient groups and civil servant groups. ${ }^{15}$

\section{Ideas}

The third "I" within the framework represents ideas, which encompass values about "what ought to be" and beliefs about "what is". "Values stem from one's personal opinion of what is right and can help to frame an issue in a certain way by individuals attempting to influence policy, such as policymakers, interest groups and the public. ${ }^{7}$ Beliefs, on the other hand, are rooted in research, tacit or local knowledge and/or personal experiences. ${ }^{7}$

\section{External factors}

Finally, external factors are outside forces which can influence policy making, such as political, economic or technological changes, the release of major reports or changes in media coverage. ${ }^{5,6}$ Such factors can generate greater public awareness of an issue and help push forward the development of policies in response to an urgent problem, or conversely, draw attention away from a policy issue. ${ }^{5,6}$ 
Due to the wide variety of factors that influence policy proposals and formulations as well as the nuanced interaction between political systems and key players, the $3 \mathrm{I}+\mathrm{E}$ framework provides a more holistic and thorough lens through which to examine all relevant components of policy decisions. It also provides a systematic approach by which to consider different elements of decision making, allowing researchers, academics and policy analysts to understand a complex decision, such as cannabis retail model selection, where information is limited.

\section{Literature search}

To examine cannabis retail policy decisions in Ontario, Saskatchewan and Quebec, two reviewers (RS and GS) independently searched newspapers, government websites, journal articles (both peer-reviewed and not peer-reviewed), press releases, government surveys and newspaper polls from January 2016 to June 2020 related to cannabis retail policies or plans. Google News and Google Search were primarily used to retrieve articles, and a search of Google Scholar and PubMed using variations of the following search terms was also conducted: cannabis retail in [province name], cannabis policy in [province name], sale of cannabis in [province name], cannabis retail stores in [province name], online retail of cannabis in [province name]. The search was iterative, and if new concepts were found during data analysis or if conceptual information was missing, new searches were conducted to fill in the gaps. English and French-language websites, documents and peer-reviewed articles that focused on cannabis retail models were included. Content focusing on cannabis legalization debate was excluded because the federal legalization policy (i.e., the Cannabis Act) was out of the scope of this policy analysis study. Reviewers compared sources found to remove duplicates and ensure the relevance of articles selected was consistent. Following this, sources were initially included in the review based on relevance to the research topic. Press releases or gray literature were excluded if they lacked appropriate references for their information, were not from credible sources (for example, mainstream media), and lacked named authors.

\section{Data analysis}

Relevant articles and news reports were first read in full, then coded in a template-style of organization following the $3 \mathrm{I}+\mathrm{E}$ framework components. The type of data from all sources was textual, qualitative and primarily in the form of public information disseminated from government officials or members of organizations that are stakeholders for cannabis retail. The data were extracted by two reviewers on a detailed summary table (see Appendix 1) which included relevant components of the framework for each province, including key government structures for that province, existing policies, prevalent interest groups, public surveys or external reports. After collecting the data, descriptive analysis was used to develop concepts and themes. ${ }^{16,17}$ Data between jurisdictions within the same component of the framework (i.e., institutions, interests, ideas, external factors) was compared, which allowed for an analysis of significant trends and themes around how each element of the framework influenced the selection of a cannabis retail model.

\section{Ethics}

No ethical approval was required for this study as it used publicly available data sources.

\section{Results}

Ontario, Saskatchewan and Quebec have populations of approximately 13.45 million, 1.10 million and 8.16 million, respectively. ${ }^{18}$ Although legalization occurred nationwide, each province had a different approach to licensing and distributing cannabis, thus Ontario has 142 authorized cannabis retail stores, while Saskatchewan and Quebec have 44 and 45 cannabis stores, respectively, as of August $252020 .{ }^{19}$ On a per-capita basis, Saskatchewan leads in the number of cannabis stores per 100,000 residents, whereas Quebec has the least number of cannabis stores per 100,000 residents. ${ }^{19}$ The specific institutions, interests, ideas and external factors that contributed to cannabis retail decisions for each province are described below and compared in Appendix 1. 


\section{Ontario}

Ontario has employed a mixed model for the retail of cannabis in the province, with storefront sales conducted through private sellers and online sales operated by the government. ${ }^{20}$

\section{Institutions}

The current premier of Ontario, Doug Ford, of the Progressive Conservative party elected in June 2018 , represents an important veto player with the power to halt laws and policies from being ratified. ${ }^{21}$ The seat distribution of the 124 seats in the Legislative Assembly of Ontario are the following: 73 Progressive Conservative, 40 New Democratic, and 8 Liberal, which effectively leads the Progressive Conservative party to an advantage as its members would vote in conformity due to party discipline. ${ }^{22}$ Premier Ford has stated that he opposes government monopolies in any industry and with his vetoing authority, any proposals for a fully public model of cannabis retail by opposing parties in Ontario would likely be dismissed. ${ }^{23}$

Moreover, Ontario has had a mixed retail model for the sale of alcohol since the Prohibition Era in which a crown corporation, the Liquor Control Board of Ontario (LCBO), and privately-owned chains, such as the Beer Store and wineries, have controlled the market. ${ }^{24}$ This represents a longstanding policy legacy, which has potential to influence the model chosen for cannabis, a substance that is similarly regulated to alcohol in many respects. Furthermore, within the last few years, Ontario has expanded alcohol sales to smaller retailers such as corner stores and grocery stores - a decision that was undertaken by the previous Liberal government and which the current Progressive Conservative government has continued to follow through on by further relaxing regulations. ${ }^{25}$ As the Ford government continues to expand alcohol privatization to small businesses, the decision to privatize cannabis storefronts parallels that of alcohol and underlines the government's disapproval of state monopolies in these industries.

\section{Interests}

Civil servant, Attorney General Caroline Mulroney has voiced support for a private retail model to better compete with the illegal market in comparison to the public model that had been previously proposed by the Liberal government. ${ }^{26}$ Similarly, certain professional groups, including the Association of Municipalities of Ontario (AMO) supported private cannabis retail to promote local job opportunities, but asked that municipalities have a strong voice in regulating the licensing and zoning of supply and retail. ${ }^{27}$ An additional reason for support may be that cannabis excise tax revenues will be shared with Ontario municipalities to manage the transition to legal recreational cannabis, with the province of Ontario committing almost $\$ 40$ million in revenue over two years to all municipalities. ${ }^{27}$

On the other hand, the Ontario Federation of Labour strongly opposed privatization, stating that it reduces government revenue, which could be used for public infrastructure projects and reduces oversight of cannabis retail. ${ }^{28}$ The Ontario Public Health Association and the City of Toronto also showed their support for a government operated retail system. ${ }^{29,30}$ Moreover, the President of the Ontario Public Service Employee Union (OPSEU), Warren (Smokey) Thomas, expressed that a public retailer would be more economically beneficial for the province. Thomas asserted his viewpoint that the government should take advantage of the opportunity to generate profit from cannabis retail. ${ }^{26}$

Another important group of stakeholders are industry groups such as the Cannabis Council of Canada, which represents licensed medical cannabis producers. Board Chair, Avtar Dhillon, spoke out in favour of the move towards privatization of recreational cannabis in Ontario to outcompete the illegal market and was in favour of oversight by the government despite privatization. ${ }^{31}$ Other special interest groups such as Aurora Cannabis, a cannabis production and distribution company, were in favour of private retail, as it would allow them to open retail stores through their Aurora Cannabis corporation. $^{32}$ 


\section{Ideas}

Beliefs and values regarding cannabis use and retail play an important role in the ideas that stakeholders have regarding retail policies. A Nanos Research Poll showed that the majority of Ontarians indicated that they had greater confidence in a public retailer's ability to safeguard youth from cannabis than a private retailer. ${ }^{26} \mathrm{~A}$ major consultation report was also released by the Government of Ontario with survey results from July 2017 regarding public opinions on cannabis legalization. $43 \%$ of respondents were equally supportive of public or private retailers, but cannabis users preferred a private model. ${ }^{33}$ The results of the survey demonstrate a public indifference that could have contributed to the Progressive Conservative party's shift to a mixed retail model.

\section{External Factors}

A significant external factor that influenced the change from a public to a mixed retail model in Ontario was a political shift from a Liberal government under Kathleen Wynne to a Progressive Conservative government under Premier Doug Ford on June 7, 2018. ${ }^{34}$ The LCBO was to be responsible for the sale of recreational cannabis under Wynne, but shortly after becoming premier, Ford indicated his preference for private storefront retail to reduce government interference in the newly-legalized recreational cannabis sector. ${ }^{35}$ The shift in government prompted discussions around economic incentives for privatization, with the new Ford government estimating savings of $\$ 150$ million from not opening exclusively publicly-run and funded cannabis stores. $^{36}$

\section{Saskatchewan}

Saskatchewan opted for a fully private model both for storefronts and online retail of recreational cannabis. While sales are conducted through private retailers, cannabis is regulated by the Saskatchewan Liquor and Gaming Authority (SLGA), the crown corporation that is also responsible for the distribution of cannabis. ${ }^{37}$

\section{Institutions}

Saskatchewan has been led by premier Scott Moe of the Saskatchewan Party, which is a right-leaning party, since January 2018. ${ }^{38}$ The seat distribution of the 61 seats of the Legislature of Saskatchewan is as follows: 46 seats for the Saskatchewan Party, 13 seats for the New Democratic Party, and two vacant seats. ${ }^{39}$ With the majority of seats currently held by the Saskatchewan Party, proposed policies are able to get passed as members of the party align their votes with the party leadership due to party discipline.

In 2016, the Saskatchewan Party introduced legislation which would permit the private retail of alcohol in the province. ${ }^{40}$ This move led to the privatization of existing liquor stores owned by the government and the creation of a dozen new privately owned stores. ${ }^{41}$ Currently, the majority of stores selling alcohol in Saskatchewan are off-sale stores, which comprise privately owned bars and restaurants, or business franchises that are licensed to sell alcohol. ${ }^{42}$ Of the 718 outlets identified by the Government of Saskatchewan, only 75 are now government liquor stores. ${ }^{42}$ The Saskatchewan Party's decision to shift a large sector of alcohol retail towards privatization has paved the way for the decision to implement a private retail model for cannabis, both of which are regulated through the SLGA.

Moreover, under the leadership of Scott Moe, the Saskatchewan Party has followed in the footsteps of previous party leader Brad Wall, in regards to widespread privatization of crown corporations and public services, something for which the party has faced criticism. ${ }^{43,44}$ The pattern of privatization favoured by Saskatchewan's ruling party and their position of power since 2007 represents a policy legacy that has contributed to the private cannabis retail model chosen in the province.

\section{Interests}

As a civil servant, the SLGA Minister, Gene Makowsky, demonstrated support for a private retail system. He describes a private retail system as less risky for taxpayers and a method to reduce over- 
involvement of the government. ${ }^{45}$ Similarly, professional groups such as the Saskatchewan Chamber of Commerce endorsed a private retail model while others, such as the Saskatchewan Government and General Employees' Union (SGEU), preferred public retail in order to invest the revenue towards infrastructure, education, and enforcement programs related to cannabis. ${ }^{46,47}$ Makowsky disagreed with this view of the SGEU regarding revenue, instead stating that an upfront cost for public cannabis retail would be too great and that money saved could instead go to the aforementioned public services, rather than revenue from cannabis. ${ }^{47}$

Special interest groups such as Super Anytime, a cannabis-technological company that provides online delivery services, and Medical Cannabis dispensaries have shown support for the private model for cannabis retail, citing better competition for the illegal market. ${ }^{45,48}$ Overall, interest groups in Saskatchewan demonstrate mixed support for the chosen model.

\section{Ideas}

Beliefs about "what is" can be established through academic research that can inform policy decisions. According to policy experts at the University of Regina and the University of Saskatchewan, privatization of cannabis distribution and retail would ensure maximum economic benefits and more effective competition with the illicit market when compared to a public model ${ }^{49}$ In contrast, the values of Saskatchewan residents can be understood through a survey conducted by the Government of Saskatchewan. The survey showed that the majority of respondents (45\%) would prefer cannabis sales to be handled through a government-run retailer, such as the SGLA, while a smaller yet significant proportion $(37 \%)$ believed sales should be done through private small business retailers. ${ }^{50}$ Despite Saskatchewan residents holding the value that cannabis retail "ought to be" public, a private model was chosen.

\section{External Factors}

There have been no major political shifts in the province's governing body since 2007, which could be a potential reason for the same type of model for cannabis being chosen as the existing model for alcohol retail within the province. ${ }^{51}$ An economic change in the direction of slowed growth may have also contributed to the private model chosen by Saskatchewan, as the struggling economy and agriculture sector could potentially benefit from the cannabis market. ${ }^{52}$ The major report released by experts at the University of Regina and University of Saskatchewan was also released in November 2017, when policy decisions were beginning to be discussed. The report may have played a role in demonstrating the economic advantages of private retail, considering the slowed growth the province was facing, as it discussed the 250 million dollars that cannabis privatization would provide to the economy of the province. ${ }^{49,53}$

\section{Quebec}

The sale of cannabis in Quebec occurs online and in-stores exclusively through the Société québécoise du cannabis (SQDC), or the Quebec Cannabis Society. ${ }^{54}$ The SQDC is a subsidiary corporation of the Société des alcools du Québec (SAQ), or Quebec Alcohol Corporation, a government-owned corporation which has a monopoly on the distribution of alcohol in the province and oversees its retail. ${ }^{55}$

\section{Institutions}

The majority government in Quebec is right-leaning and as of October 2018 has been led by Francois Legault of the Coalition Avenir Québec (CAQ), which holds 76 seats. ${ }^{56,57}$ The Quebec Liberal party holds 28 seats, the Québec solidaire holds 10 and the Parti Québécois holds 9 of 125 seats. ${ }^{56}$ Similar to Ontario and Saskatchewan, the alcohol and cannabis retail models in Quebec parallel one another. However, prominent party members in the CAQ have voiced their opposition to the government's monopoly on the sale of alcohol in the past. The previous House Leader of the CAQ, Francois Bonnardel, denounced the model of alcohol retail in the province for its excessive mark-up rates and called 
for its privatization. ${ }^{58}$ The model chosen for cannabis ultimately was not affected by the call for privatization of alcohol, and the party went ahead with a fully public model for the retail of cannabis through the SQDC.

\section{Interests}

Public Health Minister and civil servant, Lucie Charlebois, did not directly comment on whether she advocates for a private or public model. She instead described the need for more rigorous regulations with respect to the cannabis market. ${ }^{59}$ From this, it can be inferred that government officials in the province believe that a publicly-controlled retail system for cannabis would allow for "rigorous policy and implementation" as opposed to a privately controlled system.

Another important stakeholder in Quebec is the Canadian Union of Public Employees-Quebec (CUPE-Quebec), which submitted a report advocating for public retail under the Société des alcools du Québec (SAQ) during public consultations. ${ }^{60}$ Moreover, professional groups including both the Association pour la Santé Publique du Québec and the Institut national de santé publique du Québec recommended a government monopoly over the distribution and retail of cannabis. ${ }^{61,62}$

In contrast, special interest groups such as Cannabis Culture and Indigenous peoples groups, such as the Kahnawake community, cited concerns with the overly-restrictive nature of the public model. ${ }^{59,63}$ Chief Gina Deer of Kahnawake spoke against the public model and how strict provincial legislation enforcing public retail only, would supersede First Nation legislation, which they want to maintain due to concerns of addiction in First Nations populations. ${ }^{59}$ While indigenous communities have entered into the sale of cannabis under the Cannabis $A c t$, a solely public model of retail infringes on their own law-making authority to regulate traditional medicinal plants under the United Nations Declaration on the Rights of Indigenous Peoples and the Indian Act ${ }^{64}$ The interests of civil servants thus did not align with special interest groups in Quebec.

\section{Ideas}

Stricter regulations surrounding cannabis legalization in Quebec can be partly traced back to the province's religious sentiments and recent historical events. The Catholic church's legacy within the province is likely to have some influence over the beliefs and values of citizens, and by extension, cannabis legalization and retail. This is demonstrated through public polls that point to the majority of citizens being opposed or extremely opposed to the legalization of cannabis, in contrast to the opinions of the rest of Canada. Moreover, recollections of the relatively recent biker war, which was rooted within feuds over the drug trade and claimed hundreds of lives, have likely left a lasting impact on Quebecers' beliefs towards the legalization and use of recreational drugs, including cannabis. ${ }^{65}$ As a result, citizens of the province may be more likely to lean towards greater government control of the substance throughout the supply chain, including retail. On the other hand, it may be possible that younger, college-aged students disagree with this, as demonstrated by a commentary piece written by a McGill student describing his perspective on the limitations of a public cannabis retail model. ${ }^{66}$

The values of Quebec residents can be better understood through citizen surveys. A poll highlighted the majority of Quebeckers' disapproval of the impending legislation, with $54 \%$ of respondents opposing the legalization of cannabis and a third strongly against legalization. ${ }^{67}$ Consequently, it is likely that strict government control of cannabis retail is favoured by residents when compared to a private model, as a majority of citizens have a negative view when it comes to legalization of the substance in the first place.

\section{External Factors}

Although a new government was elected in Quebec two weeks prior to recreational cannabis being legalized, there was no change in policy regarding the chosen retail model in the province. ${ }^{68}$ Similarly, no major economic changes were found to have influenced the province's policy. In fact, the Finance Minister of Quebec, Carlos Leitao, stated that 
cannabis retail is not expected to be a large source of revenue for the province, once again highlighting the sociocultural factors surrounding cannabis use and legalization by Quebec residents and officials. ${ }^{69}$

\section{Discussion}

The application of the $3 \mathrm{I}+\mathrm{E}$ framework for cannabis retail policy demonstrates the varying influence that government institutions, interest groups, ideas and external factors have on policy making. The current provincial parties of Ontario, Saskatchewan and Quebec are right-leaning and each of the provinces have a majority government with strong party discipline. Despite the similarities in government structures within each of the examined provinces, three different models for cannabis retail were chosen by their respective governments. This can largely be attributed to the policy legacies for alcohol retail in the jurisdictions, which demonstrate that cannabis retail models were made to parallel existing policies for alcohol. For example, Ontario has a mixed model for the sale of alcohol, which helps explain the mixed model that was also chosen for cannabis. In Saskatchewan, alcohol retail has been predominantly shifted to the private sector in recent years, laying the foundation for an exclusively private model for the sale of cannabis. Conversely, alcohol retailers in Quebec are solely crown-operated, creating an existing policy upon which the province based their public cannabis retail model. It is important to note that existing alcohol policies may have been informed by the ideas (beliefs and values) of the public and other stakeholders, demonstrating the interconnected influence of the components of the 3I+E framework.

The formation of policy networks can lead to significant sway in decision-making through input from outside interests. However, the existence of any particular policy network influencing cannabis retail decisions is unlikely as we did not find evidence of established committees consisting of the respective provincial government and stakeholders (such as the LCBO, the SGLA, the SQDC, private corporations or interest groups) that were mandated to make decisions related to cannabis retail models.
Despite the absence of organized policy networks, various interest groups offered their perspectives and advocated for particular retail models and regulations. In response to the call for submissions by the Government of Canada's Task Force on Marijuana Legalization and Regulations, over 300 organizations provided written submissions that outlined their concerns and recommendations regarding the legalization of recreational cannabis. ${ }^{3}$ Many nation-wide special interest groups, including Mothers Against Drunk Driving (MADD) Canada and Families for Addiction Recovery, supported government retail of cannabis over private retail outlets. ${ }^{70,71}$ Other special interest groups, including patient groups, religious groups and professional health care groups, were not found to have a stance for or against a particular model for cannabis retail; instead, they were more invested in the national regulations surrounding cannabis legalization itself. ${ }^{3}$ In contrast, cannabis industry groups were one type of special interest group that took to media to express a more active stance on cannabis retail models ${ }^{3}$, potentially due to their economic incentives in the retail model chosen.

When examining the three jurisdictions and their respective interest groups, it is clear that the majority of professional interest groups advocated for public retail models, with the exception of the Saskatchewan Chamber of Commerce, while all special interest groups (i.e., cannabis industry groups) pushed for the privatization of cannabis retail. In Ontario and Saskatchewan, many special interest groups described the potential benefit of a private market as being better able to replace the illegal market. Cannabis retailers used this as an argument in favour of privatization, when in reality, this has not been the case in California, where despite legal recreational cannabis businesses being available, the illegal market continues to thrive. ${ }^{72}$ The case of cannabis retail policy demonstrates that special interest groups favoured privatization, likely due to financial incentives. Moreover, the model favoured by the majority of civil servant-based interest groups was chosen. Excluding the City of Toronto, civil servants in Ontario and Saskatchewan recommended a free market for the retail sale of cannabis 
whereas Quebec's Public Health Minister pushed for more government oversight.

Beliefs and values of citizens around cannabis retail were demonstrated through surveys that indicated either a majority or at least half of survey respondents preferred a public retail model in all three jurisdictions. However, only in Quebec did citizen values align with the provincial government's actual decision to make cannabis retail public, relating back to the historical and cultural differences unique to Quebec. Citizen polls demonstrated that citizens desire an increase in public sector revenue, but also wish for small businesses to have an opportunity to benefit from cannabis retail, which are both contradictory ideas of what "ought to be".

When examining external factors through the $3 \mathrm{I}+\mathrm{E}$ framework, it is evident that the political shift in Ontario from a Liberal majority to a Progressive Conservative majority government strongly influenced the province's decision to switch from a public to mixed model of cannabis retail. The newly elected Premier strongly advocated for private retail, and the Ford government presented the positive economic change resulting from non-public cannabis stores at a critical time in the policy-making process in order to change the previously chosen Liberal model. In contrast, the potential for positive economic growth from a struggling economy in Saskatchewan was an external factor more likely to contribute to their decision to privatize, as the province experienced no political change. Quebec did have a political change, but unlike Ontario, it did not have as drastic an effect. Overall, this comparative analysis demonstrates that the components influencing the policy decisions for cannabis retail in each jurisdiction were multifactorial, with some factors, such as policy legacies and government institutions, playing a larger role than others, such as the ideas and beliefs of citizens.

\section{Public Health Implications}

When examining the public health implications of private cannabis retail, we can look to jurisdictions where legalization has taken place in the United States. The state of Colorado legalized recreational marijuana in 2012, implemented a private retail model, and requires private retailers to obtain licenses along with being subjected to retail marijuana excise tax and sales tax. ${ }^{73,74}$ Since then, researchers have looked at various dimensions of cannabis and its public health implications including cannabis use among youth, crime rates, traffic incidences, hospital and rehabilitation visits, deaths and suicide rates and revenues. Since 2014, Colorado has experienced a rise in criminal networks and evidence of black-market marijuana and higher hospitalizations related to marijuana, with emergency department visits increasing from 22 per 100,000 people in 2012 to 38 per 100,000 shortly after commercial sale of recreational marijuana was introduced in $2014 .^{74}$ However, legal marijuana has also contributed $\$ 1$ billion in Colorado state revenue, part of which has been allocated to public departments such as The Colorado Education Department. ${ }^{74,75}$

It is evident that the public health ramifications of cannabis use are significant, and the model that is chosen for distribution impacts the extent to which these public health dimensions are influenced. For instance, public models will generate revenue that can be used towards public services. On the other hand, more relaxed government control, a potential side-effect of private retail models, has the potential to influence cannabis use in youth ${ }^{76}$, which is linked to mental illness and poorer school performance. ${ }^{77}$ Retail model decisions also have implications for vulnerable populations. For instance, private retailers may take advantage of the increased frequency of cannabis use among certain populations and select retail locations accordingly. ${ }^{78}$ Due to the wide implications of the cannabis retail model a jurisdiction selects, it is important to understand how policy decisions came to be.

It is helpful to know which factors played a more or less significant role in cannabis retail policy formulation, as that information can be used to both understand and influence future public health policy decisions such as policies around education of cannabis use, underage cannabis use, cannabis-impaired driving issues and the impact of legalization on vulnerable populations. This information can 
also inform us on which factors are most helpful for bringing a new or emerging policy decision to the forefront.

\section{Strengths and limitations}

One limitation of this study is that it did not include qualitative interviews with key stakeholders involved in the decision-making process for cannabis retail policies. However, we were able to use a wide variety of sources including media articles, government press releases, public polls, reports and policy literature to understand key factors that contributed to the decision in each jurisdiction. Further qualitative research through interviews with key stakeholders that were involved in the decision-making process can be used to build on the findings of this study which only included secondary sources. To our knowledge, this is the first study to conduct an analysis of policy decisions around public, private and mixed cannabis retail models implemented in Canadian provinces. The comparative approach used allows for finding points of similarity or divergence between jurisdictions that chose differing models, allowing the results to be generalizable to other jurisdictions or States considering cannabis legalization.

\section{Conclusion}

This paper presents the $3 \mathrm{I}+\mathrm{E}$ framework and how it can be used to evaluate the adoption of policy alternatives within specific jurisdictions. All three provincial governments of Ontario, Saskatchewan and Quebec are right-leaning and hold a majority of seats in their respective legislatures, yet three different models of cannabis sale options were adopted within each jurisdiction: Ontario with a mixed model, Saskatchewan with a private model and Quebec with a public model. By analyzing the relevant institutions, interests, ideas and external factors at play, our study found that policy legacies and opinions of prominent civil servants seem to be the main driver of these policies. Professional groups and the public were in favour of public and private models with some level of government involvement while cannabis retailers were in favour of privatization, likely for economic incentives.
This paper highlights areas of further study to realize an in-depth understanding of the roles of each factor on the policy decision process. Moreover, the $3 \mathrm{I}+\mathrm{E}$ framework can also be used to later predict or propose how different jurisdictions in Canada will react towards enacting public health measures related to cannabis legalization.

\section{Competing interests}

None declared

\section{Funding statement}

No funding was received for this publication

\section{References}

1. Cox C. The Canadian Cannabis Act legalizes and regulates recreational cannabis use in 2018. Health Policy. 2018;122(3):205-209. doi:10.1016/j.healthpol.2018.01.009

2. Government of Canada. The constitutional distribution of legislative powers. Government of Canada. Published July 25, 2018. Accessed April 3, 2020. https://www.canada.ca/en/intergovernmental-affairs/services/federation/distribution-legislative-powers.html

3. McLellan A, Ware MA, Boyd S, et al. A Framework for the Legalization and Regulation of Cannabis in Canada: The Final Report of the Task Force on Cannabis Legalization and Regulation. Health Canada; 2016. Accessed February 7, 2020. http://www.deslibris.ca/ID/10064626

4. Shearer JC, Abelson J, Kouyaté B, Lavis JN, Walt G. Why do policies change? Institutions, interests, ideas and networks in three cases of policy reform. Health Policy Plan. 2016;31(9):1200-1211. doi:10.1093/heapol/czw052

5. Pomey M-P, Morgan S, Church J, et al. Do provincial drug benefit initiatives create an effective policy lab? The evidence from Canada. J Health Polit Policy Law. 2010;35(5):705-742. doi:10.1215/03616878-2010-025

6. Howlett M, Perl A, Ramesh M. Studying Public Policy: Policy Cycles \& Policy Subsystems. Oxford University Press; 2009.

7. Gauvin F-P. Understanding Policy Developments and Choices through the "3-i" Framework: Interests, Ideas and Institutions. National Collaborating Centre for Healthy Public Policy; 2014. Accessed June 25, 2020. http://www.ncchpp.ca/165/publications.ccnpps?id_article $=1077$

8. House of Commons Canada. The Canadian Parliamentary system House of Commons Canada. Accessed June 25, 2020. https://www.ourcommons.ca/About/OurProcedure/ParliamentaryFramework/c_g_parliamentaryframework-e.htm

9. Tsebelis G. Decision making in political systems: Veto players in Presidentialism, Parliamentarism, Multicameralism and Multipartyism. British Journal of Political Science. 1995;25(3):289-325. 
10. Hynes S, Johnston L. How an Ontario Bill Becomes Law. Legislative Research Service; 2011. Accessed April 4, 2020. https://www.ola.org/sites/default/files/common/how-bills-becomelaw-en.pdf

11. Torfing J. Rethinking path dependence in public policy research. Critical Policy Studies. 2009;3(1):70-83.

doi:10.1080/19460170903158149

12. Lavis JN, Røttingen J-A, Bosch-Capblanch X, et al. Guidance for evidence-informed policies about health systems: Linking guidance development to policy development. PLoS Med. 2012;9(3):e1001186. doi:10.1371/journal.pmed.1001186

13. Cashore B, Vertinsky I. Policy networks and firm behaviours: Governance systems and firm responses to external demands for sustainable forest management. Policy Sciences. 2000;33(1):1-30

14. Pal LA. Public Policy Analysis: An Introduction. Nelson Canada; 1992.

15. Walt G. Health policy: An introduction to process and power. Published online 1994. Accessed June 25, 2020 https://trove.nla.gov.au/version/36582878

16. Brooks J, McCluskey S, Turley E, King N. The utility of template analysis in qualitative psychology research. Qual Res Psychol. 2015;12(2):202-222. doi:10.1080/14780887.2014.955224

17. Sandelowski M. Whatever happened to qualitative description? Res Nurs Health. 2000;23(4):334-340. doi:10.1002/1098240x(200008)23:4<334::aid-nur9>3.0.co;2-g

18. Statistics Canada. Population and dwelling count highlight tables, 2016 Census. Published February 8, 2017. Accessed December 21 2020. https://www12.statcan.gc.ca/census-recensement/2016/dp$\mathrm{pd} / \mathrm{hlt}-\mathrm{fst} / \mathrm{pd}-\mathrm{pl} / \mathrm{Comprehensive.cfm}$

19. Israel S. Ontario, Canada, to double pace of new cannabis store approvals. Marijuana Business Daily. Published September 1, 2020. Accessed December 21, 2020. https://mjbizdaily.com/ontario-todouble-pace-of-new-cannabis-store-approvals/

20. Ontario announces cannabis retail model. Ontario Newsroom. Published August 13, 2018. Accessed July 1, 2021. https://news.ontario.ca/en/release/49874/ontario-announces-cannabis-retail-model

21. Benzie R. Doug Ford is Ontario's next premier. Toronto Star. https://www.thestar.com/news/queenspark/2018/06/07/doug-fordon-track-to-be-ontarios-next-premier.html. Published June 8, 2018. Accessed December 21, 2020.

22. Legislative Assembly of Ontario. MPPs are your representatives in the Legislative Assembly of Ontario. Legislative Assembly of Ontario. Accessed April 3, 2020. https://www.ola.org/en/members

23. Miller J. Canopy Growth empire expands as company wins joint bid to run marijuana stores in Manitoba | Ottawa Citizen. Published February 16, 2018. Accessed February 7, 2020. https://ottawacitizen.com/news/local-news/canopy-growth-empire-expands-as-company-wins-joint-bid-to-run-marijuana-stores-in-manitoba

24. Crépault J-F, Wettlaufer A. Alcohol policy framework. Published online 2019.

25. Myran D. Opinion: Ontario has an alcohol crisis - and the government is making it worse. The Globe and Mail. https://www.theglobeandmail.com/opinion/article-ontario-has-an-alcohol-crisis-and- the-government-is-making-it-worse/. Published April 12, 2019. Accessed February 7, 2020

26. Artuso A. Poll shows public unease with private pot stores: OPSEU Toronto Sun. https://torontosun.com/cannabis/cannabis-news/pollshows-public-unease-with-private-pot-stores-opseu. Published October 11, 2018. Accessed December 24, 2019.

27. AMO (Association of Municipalities Ontario). Cannabis implementation- Retail consultation. Association of Municipalities Ontario. Published August 13, 2018. Accessed December 24, 2019. https://www.amo.on.ca/CannabisImplementation

28. Perry M. Push toward privatization of cannabis sales will hurt the people of Ontario, says OFL. The Ontario Federation of Labour. Published July 27, 2018. Accessed December 24, 2019. http://ofl.ca/push-toward-privatization-of-cannabis-sales-will-hurtthe-people-of-ontario-says-ofl/

29. Akhigbe J, Ebbadi V, Huynh K, et al. The Public Health Implications of the Legalization of Recreational Cannabis - Ontario Public Health Association Position Paper. Ontario Public Health Association; 2017.

30. Cook T. City of Toronto Recommendations for cannabis legalization. Published online September 2017.

31. Jones RP. Ontario to allow private retailers to sell cannabis, province will handle online sales. $C B C$ News.

https://www.cbc.ca/news/canada/toronto/ontario-cannabis-privatesales-1.4783630. Published August 14, 2018. Accessed September $6,2019$.

32. CBC News. Ontario's private sector retail cannabis plan draws pot industry approval. CBC News. https://www.cbc.ca/news/business/cannabis-ontario-private-retail-1.4784703. Published August 14, 2018. Accessed December 24, 2019.

33. Government of Ontario. Consultation Report: Cannabis Legalization in Ontario. Government of Ontario; 2017. Accessed December 28, 2019. https://www.ontario.ca/page/consultation-report-cannabislegalization-ontario

34. Powers L. "We have taken back Ontario": Doug Ford leads PCs to majority government. CBC News. https://www.cbc.ca/news/canada/toronto/ontario-election-vote-ford-horwath-wynne-pc-ndp-liberal-green-1.4696736. Published June 7, 2018. Accessed December $28,2019$.

35. The Canadian Press. Ontario to allow private retailers to sell cannabis, report says. CBC News. https://www.cbc.ca/news/canada/toronto/cannabis-ontario-private-retailers-ford-1.4763921. Published July 27, 2018. Accessed December 28, 2019.

36. Loriggio $\mathrm{P}$, Jeffords S. Ontario could see up to 1,000 private pot shops after cannabis legalization. CTVNews.

https://www.ctvnews.ca/business/ontario-could-see-up-to-1-000-private-pot-shops-after-cannabis-legalization-1.4112382. Published September 27, 2018. Accessed December 28, 2019.

37. SLGA (Saskatchewan Liquor and Gaming Authority). About SLGA. Saskatchewan Liquor and Gaming Authority. Accessed December 28, 2019. https://www.slga.com/about-slga/slga

38. Government of Saskatchewan. Honourable Scott Moe. Government of Saskatchewan. Accessed December 21, 2020. https://www.saskatchewan.ca/government/government-structure/cabinet/honourable-scott-moe 
39. Legislative Assembly of Saskatchewan. Members of the Legislative Assembly. Legislative Assembly of Saskatchewan. Accessed April 3, 2020. https://www.legassembly.sk.ca/mlas/

40. Global News. Saskatchewan introduces bill to privatize liquor stores. Global News. Published May 24, 2016. Accessed February 7, 2020. https://globalnews.ca/news/2719690/saskatchewan-introduces-bill-to-privatize-liquor-stores/

41. Government of Saskatchewan. Liquor Retail Modernization Act, 2016 Introduced | News and Media. Government of Saskatchewan. Published June 16, 2016. Accessed April 3, 2020. https://www.saskatchewan.ca/government/news-and-media/2016/june/06/liquor-retail-modernization-act

42. Government of Saskatchewan. About Liquor Retailing | Liquor Retail in Saskatchewan. Government of Saskatchewan. Accessed April 3, 2020. https://www.saskatchewan.ca/government/public-consultations/past-consultations/future-options-for-liquor-retailing-in-saskatchewan/about-liquor-retailing\#history-of-liquor-retailing-in-saskatchewan

43. PressProgress. The Saskatchewan Party promised no privatization They sold over \$1 Billion in public assets instead. PressProgress. Published March 9, 2018. Accessed April 3, 2020. https://pressprogress.ca/the-saskatchewan-party-promised-no-privatization-theysold-over-1-billion-in-public-assets-instead/

44. Unifor. Moe's first budget continues failed policies. Unifor National. Published April 10, 2018. Accessed April 3, 2020. https://www.unifor.org/en/whats-new/press-room/moes-firstbudget-continues-failed-policies

45. Fraser RDC. Private retailers to sell cannabis in Saskatchewan. Reginal Leader-Post. https://leaderpost.com/news/saskatchewan/weedto-be-sold-in-sask-by-private-retailers. Published January 9, 2018. Accessed December 28, 2019.

46. Saskatchewan Chamber of Commerce. Legalization of Cannabis Backgrounder. Published online January 2018. https://saskchamber.com/isl/uploads/2019/05/Backgrounder_SCC_Legalization-ofCannabis_FINAL-DRAFT-_JANUARY-16-2018.pdf

47. Giles D. SGEU baffled private sector will be handling marijuana sales in Saskatchewan. Global News. https://globalnews.ca/news/3956140/sgeu-private-sector-marijuana-sales-saskatchewan/. Published January 10, 2018. Accessed June 29, 2020.

48. Subramaniam V. Saskatchewan and Manitoba emerge as testing grounds for same-day cannabis delivery. Financial Post. https://business.financialpost.com/cannabis/cannabis-business/saskatchewan-and-manitoba-emerge-as-testing-grounds-for-same-daycannabis-delivery. Published July 2, 2019. Accessed December 28, 2019

49. Bojkovsky C, Callan D, Childs J, Hartner G, Konecsni J, McNutt K. Legalizing \& Regulating Cannabis in Saskatchewan. Johnson Shoyama Graduate School of Public Policy.; 2017.

50. Government of Saskatchewan. Saskatchewan's Cannabis Framework: Framework and Survey Results. Government of Saskatchewan; 2017.

51. Saskatchewan Party. Our History. Saskatchewan Party. Accessed December 28, 2019. https://www.saskparty.com/our_history

52. Muthukumaran R. Saskatchewan- Weak Growth Expected. Royal Bank of Canada; 2019. Accessed December 28, 2019. http://www.rbc.com/economics/economic-reports/provincial-economic-forecasts.html

53. CBC News. "A big economic impact": Legalized cannabis could be $\$ 250 \mathrm{M}$ market in Sask., report says. CBC News.

https://www.cbc.ca/news/canada/saskatchewan/saskatchewan-cannabis-sales-report-1.4404306. Published November 16, 2017. Accessed December 28, 2019.

54. Government of Quebec. Cadre légal. Encadrement du cannabis au Québec. Accessed April 16, 2020. https://encadrementcannabis.gouv.qc.ca/loi/

55. SQDC (Société québécoise du cannabis). Our Mandate \& Mission. SQDC. Accessed April 16, 2020. https://www.sqdc.ca/en-CA/aboutthe-sqde/the-sqdc?origin=footer $\& \mathrm{c} 1=$ about $\& \mathrm{c} 2=$ thesqde\&clickedon=the-sqde

56. Assemblée nationale du Québec. Members - National Assembly of Québec. Accessed June 29, 2020. http://www.assnat.qc.ca/en/deputes/index.html

57. Montpetit J. Who is François Legault, Quebec's next premier? $C B C$ News. https://www.cbc.ca/news/canada/montreal/francois-legaultpremier-1.4846308. Published October 2, 2018. Accessed December $21,2020$.

58. CAQ (Coalition Avenir Québec). À quand la fin du monopole de la SAQ? Coalition Avenir Québec. Published May 25, 2016. Accessed April 16, 2020. https://coalitionavenirque-

bec.org/fr/blog/2016/05/25/a-quand-la-fin-du-monopole-de-la-saq/

59. Valiante G. Quebec felt heavy public pressure to table strict marijuana law: stakeholders. CityNews. https://toronto.citynews.ca/2017/11/16/quebec-expected-to-table-cannabislegislation-today/. Published November 16, 2017. Accessed December $28,2019$.

60. CUPE (Canadian Union of Public Employees). Distribution of marijuana: concerns remain. Canadian Union of Public Employees. Published October 24, 2017. Accessed December 28, 2019. https://cupe.ca/distribution-marijuana-concerns-remain

61. Chapados M, Gagnon F, Lapointe G, et al. Légalisation Du Cannabis à Des Fins Non Médicales: Pour Une Régulation Favorable à La Santé Publique. Institut national de santé publique du Québec; 2016. Accessed June 2, 2020. https://www.deslibris.ca/ID/10091163

62. Association pour la santé publique du Québec. La Légalisation Du Cannabis: Prévention et Santé Avant Tout. Association pour la santé publique du Québec; 2017. http://www.aspq.org/documents/file/2017_04_07_legalisation_cannabis_aspq_enonce_position_z.pdf

63. Valiante G. Quebec unveils 'rigorous' legalized-marijuana laws, while Alberta embraces the private sector. National Post. https://nationalpost.com/news/politics/quebec-expected-to-table-cannabislegislation-today. Published November 16, 2017. Accessed December $28,2019$.

64. Donovan J. Canada must respect Indigenous cannabis laws. Policy Options. Published August 1, 2019. Accessed July 1, 2021 https://policyoptions.irpp.org/magazines/august-2019/canada-mustrespect-indigenous-cannabis-laws/

65. Peritz I. Quebec set to become the most restrictive province in Canada for cannabis use. The Globe and Mail. https://www.theglobeandmail.com/cannabis/article-quebec-set-to-become-the-most- 
restrictive-province-in-canada-for/. Published October 8, 2018. Accessed April 18, 2020.

66. Sailer J. Quebec is legalizing cannabis - barely. The McGill Tribune. http://www.mcgilltribune.com/opinion/quebec-is-legalizingcannabis-barely-2409/. Published September 25, 2018. Accessed June 26, 2020.

67. Montreal Gazette. Quebecers break ranks with Canada, and oppose legal weed: poll. Montreal Gazette. https://montrealgazette.com/news/national/quebecers-break-ranks-with-canada-andoppose-legal-weed-poll. Published May 30, 2017. Accessed April $18,2020$.

68. Hannay C, Blackley S, Peritz I, Perreaux L, Seguin R, Ha TT. Quebec election 2018: Coalition Avenir Québec wins historic majority. The Globe and Mail. https://www.theglobeandmail.com/politics/article-quebec-election-2018-live-updates/. Published October 1 , 2018. Accessed December 28, 2019.

69. Shingler B. Quebec moves cautiously — and reluctantly — on legal cannabis sales. CBC News. https://www.cbc.ca/news/canada/montreal/quebec-cannabis-marijuana-legalization-1.4702260. Published June 14, 2018. Accessed December 28, 2019.

70. Soloman R, Chamberlain E, Al-Azem N. Submission to the Task Force on Marijuana Legalization and Regulation. MADD Canada; 2016

71. Hamilton A. Submission to The Task Force On Marijuana Legalization and Regulation. Families for Addiction Recovery; 2017:16.

72. Romero D. California's cannabis black market has eclipsed its legal one. NBC News. https://www.nbcnews.com/news/us-news/california-s-cannabis-black-market-has-eclipsed-its-legal-one-n1053856. Published September 20, 2019. Accessed February 7, 2020.

73. Colorado Department of Revenue. Marijuana Tax. Colorado Department of Revenue- Taxation Divison. Published November 7, 2019. Accessed June 2, 2020. https://www.colorado.gov/pacific/tax/marijuana-tax

74. Zvonarev V, Fatuki TA, Tregubenko P. The public health concerns of marijuana legalization: An overview of current trends. Cureus. 2019;11(9):e5806. doi:10.7759/cureus.5806

75. Rosenbaum E. Colorado passes $\$ 1$ billion in marijuana state revenue. CNBC. Published June 12, 2019. Accessed June 2, 2020 https://www.cnbc.com/2019/06/12/colorado-passes-1-billion-in-marijuana-state-revenue.html

76. Caulkins JP, Kilborn ML. Cannabis legalization, regulation, \& control: A review of key challenges for local, state, and provincial officials. The American Journal of Drug and Alcohol Abuse. 2019;45(6):689-697. doi:10.1080/00952990.2019.1611840

77. Grant CN, Bélanger RE. Cannabis and Canada's children and youth Paediatr Child Health. 2017;22(2):98-102. doi:10.1093/pch/pxx017

78. Spence N, Wells S, George J, Graham K. An examination of marijuana use among a vulnerable population in Canada. $J$ Racial Ethn Health Disparities. 2014;1(4):247-256. doi:10.1007/s40615-0140031-5 